\title{
ANALISIS KORESPONDENSI UNTUK MENGETAHUI KETERKAITAN TINDAK PIDANA DENGAN USIA, JENIS KELAMIN, TINGKAT PENDIDIKAN, PEKERJAAN DAN ALASAN MELAKUKAN TINDAK PIDANA
}

\author{
Wara Pramesti \\ Program Studi Statistika \\ Universitas PGRI Adi Buana Surabaya
}

\begin{abstract}
ABSTRAK
Analisis korespondensi merupakan sebuah teknik multivariat secara grafik yang digunakan untuk eksplorasi data dari sebuah tabel kontingensi. Analisis korespondensi ini bertujuan untuk melihat ada tidaknya hubungan antara variabel secara visual, sekaligus dapat digunakan untuk melihat keterkaitan (kedekatan) suatu kategori pada satu peubah terhadap kategori peubah lainnya.

Objek yang diamati adalah tindak pidana dan pelaku tindak pidana berdasarkan usia, jenis kelamin, tingkat pendidikan, pekerjaan dan alas an melakukan tindak pidana yang terjadi di Rumah Tahanan Gresik. Berdasarkan hasil analisis korespondensi sederhana menurut usia tindak pidana narkoba, penganiayaan dan perjudian cenderung dilakukan oleh anak-remaja, tindak pidana pencurian, penadahan dan penipuan cenderung dilakukan oleh usia dewasa, usia tua banyak melakukan tindak pidana gangguan keamanan dan perjudian. Berdasarkan tingkat pendidikan mereka yang tidak lulus SD cenderung melakukan tindak pidana perjudian, pencurian dan penganiayaan. Pencurian dan penipuan banyak dilakukan oleh tingkat pendidikan SMP dan pelaku tindak pidana dengan tingkat pendidikan SMA-PT banyak melakukan tindak pidana narkoba. Pelaku tindak pidana denngan alas an ekonomi banyak melakukan tindak pidana pencurian, penipuan dan penadahan, tindak pidana perjudian banyak dilakukan oleh mereka yang mempunyai alas an lingkungan dan tindak pidana penganiayaan dan gangguan keamanan banyak dilakukan oleh mereka yang mempunyai alas an melakukan tindak pidana karena keluarga dan dendam.
\end{abstract}

Kata kunci : analisis korespondensi, tindak pidana, pelaku tindak pidana.

\section{Pendahuluan}

Analisis korespondensi yang tergolong dalam analisis eksplorasi data peubah ganda, merupakan analisis yang memperagakan baris dan kolom secara serempak dari tabel kontingensi dwi arah (crosstab) yang berisi informasi tentang frekuensi atau prosentase dari kategori-kategori penyusunnya. Data untuk penyajian crosstab pada umumnya adalah data kualitatif, khususnya.

Dari tabel kontingensi dwi arah (crosstab) tersebut, salah satu informasi yang ingin diketahui adalah ada tidaknya keterkaitan antar kategori. Untuk menguji kebebasan ini statistik uji yang digunakan adalah Chi-square, bila antar kategori tersebut tidak saling terkait (bebas), dapat diartikan bahwa besarnya frekuensi (nilai) profil pada suatu kategori tidak dipengaruhi oleh profil pada kategori lainnya. Akan tetapi bila kebebasan antar kategori tersebut tidak dapat dibuktikan, maka hal yang selalu ingin diketahui adalah profil-profil mana yang saling terkait tersebut.

Analisis korespondensi dapat digunakan untuk melihat secara visual ada tidaknya ketergantungan antar kategori, juga sekaligus dapat membantu melihat keterkaitan suatu profil dari suatu kategori terhadap profil dari kontingensi, menjadi komponen baris dan kolom. Hasil dari analisis ini kemudian ditampilkan dalam bentuk gambar dua dimensi dengan menumpang tindihkan (overlay) antara profil-profil baris dan kolom. 


\section{Tinjauan Pustaka}

2.1. Tabel Kontingensi Dua Arah

Tabel kontingensi dua arah adalah tabel yang mencatat data hasil pengamatan dengan melibatkan dua variabel $\mathbf{X}$ dan $\mathbf{Y}$. Tabel kontingensi dua arah ini digunakan untuk menguji independensi antara dua variabel $\mathbf{X}$ dan $\mathbf{Y}$.

Variabel $\mathbf{X}$ terbagi atas $\mathbf{b}$ taraf atau tingkatan dan variabel $\mathbf{Y}$ terbagi atas $\mathbf{k}$ taraf atau tingkatan. Banyaknya pengamatan yang terjadi karena taraf ke-i variabel $\mathbf{X}(\mathbf{i}=\mathbf{1}, \mathbf{2}, \ldots, \mathbf{b})$ dan taraf ke-j variabel $\mathbf{Y}(\mathbf{j}=\mathbf{1 , 2}, \ldots, \mathbf{k})$ akan dinyatakan dengan $\mathbf{O}_{\mathbf{i j} .}$.Hasil pengamatan dapat ditunjukkan sebagai berikut :

TABEL KONTINGENSI b X k UNTUK HASIL PENGAMATAN TERDIRI DARI DUA VARIABEL

\begin{tabular}{|c|c|c|c|c|c|c|}
\hline & \multicolumn{4}{|c|}{ VARIABEL Y ( $k$ taraf ) } & \multirow[t]{2}{*}{ JUMLAH } \\
\hline & & 1 & 2 & & $\mathbf{K}$ & \\
\hline \multirow{4}{*}{ 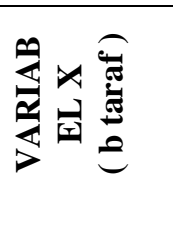 } & $\mathbf{1}$ & $\mathrm{O}_{11}$ & $\mathrm{O}_{12}$ & $\ldots$ & $\mathrm{O}_{1 \mathrm{~K}}$ & $\mathrm{n}_{10}$ \\
\hline & 2 & $\mathrm{O}_{21}$ & $\mathrm{O}_{22}$ & $\ldots$ & $\mathrm{O}_{2 \mathrm{~K}}$ & $\mathrm{n}_{20}$ \\
\hline & $\vdots$ & & & & $\vdots$ & $\vdots$ \\
\hline & B & $\mathrm{O}_{\mathrm{b} 1}$ & $\mathrm{O}_{\mathrm{b} 2}$ & $\ldots$ & $\mathrm{O}_{\mathrm{bk}}$ & $\mathrm{O}_{\mathrm{bo}}$ \\
\hline JUMLAH & & $\mathrm{n}_{01}$ & $\mathrm{n}_{02}$ & & $\mathrm{n}_{0 \mathrm{k}}$ & $\mathrm{N}$ \\
\hline
\end{tabular}

Pasangan hipotesis yang akan di uji berdasarkan data seperti dalam daftar di atas adalah :

$\mathrm{H}_{0}$ : kedua variabel independen (bebas)

$\mathrm{H}_{1}$ : kedua variabel dependen (tidak bebas)

Uji yang sesuai untuk mengetahui ada tidaknya hubungan antara dua variabel kategori yang berupa tabel kontingensi, adalah uji chi-square.

Langkah-langkah pengujian chi-square adalah sebagai berikut :

1) Menentukan hipotesis nol :

$\mathrm{H}_{0}$ : Kedua variabel independen

$\mathrm{H}_{1}$ : Kedua variabel dependen

2) Menentukan frekuensi harapan $\left(E_{i j}\right)$ tiap sel data

$E i j=\frac{b_{i} k_{j}}{N}$

$b_{i}=$ banyaknya pengamatan dalam baris ke- $\mathrm{i}$

$\mathrm{k}_{\mathrm{j}}=$ banyaknya pengamatan dalam kolom ke- $\mathrm{j}$

$\mathrm{N}$ = banyaknya data yang diamati

3) Menghitung nilai chi-square $\left(\chi^{2}\right)$

$$
\chi^{2}=\sum_{i=1}^{b} \sum_{j=1}^{k} \frac{(O i j-E i j)^{2}}{E i j}
$$

$\mathrm{O}_{\mathrm{ij}}=$ Nilai frekuensi amatan

$\mathrm{E}_{\mathrm{ij}}=$ Nilai frekuensi harapan

4) Menentukan daerah penolakan atau daerah kritis

Ho ditolak bila :

$\chi^{2}>\chi_{\alpha(k-1)(b-1)}^{2}$

Keterangan :

$\alpha=$ Tingkat kesalahan yang diambil

$(\mathrm{k}-1)(\mathrm{b}-1) \quad=$ derajat bebas 
5) Kesimpulan

Bila statistik uji berada dalam daerah kritis atau dapat juga dikatakan jika $\chi_{\text {rasio }}^{2}>\chi_{\text {tabel }}^{2} \chi^{2}$ tabel maka $\mathrm{H}_{0}$ ditolak, yang berarti bahwa dua variabel tersebut tidak saling bebas (dependen).

\subsection{Analisis Korespondensi}

Analisis korespondensi merupakan analisis yang memperagakan baris dan kolom secara serempak dari tabel kontingensi dwi arah, yang kemudian dapat diperluas untuk tabel kontingensi multi arah. Peragaan yang diperoleh merupakan penumpang tindihan profil profil baris dan kolom, yang dalam analisis ini diperoleh dari tabel kontingensi dengan menggunakan jarak khi - kuadrat. Penggunaan Penguraian Nilai Singular umum (Generalized Singular Value Decomposition) dalam perhitungan analisis ini akan memberikan keterkaitannya dengan analisis lain dalam multivariat.

\subsubsection{Matriks Data}

Jika $\mathbf{N}$ adalah matriks data yang unsur-unsurnya merupakan bilangan positif berukuran $\boldsymbol{I} \boldsymbol{x} \boldsymbol{J}$ dimana $\boldsymbol{I}$ menunjukkan baris dan $\boldsymbol{J}$ menunjukkan kolom, maka $\mathbf{P}$ adalah Matriks korespondensi didefinisikan sebagai matriks yang unsur-unsurnya adalah unsur matriks $\mathbf{N}$ yang telah dibagi dengan jumlah total unsur matriks $\mathbf{N}$. Vektor jumlah baris dan kolom dari matriks $\mathbf{P}$ masing-masing dinotasikan dengan $\mathbf{r}$ dan c. Matrik diagonal dari elemen - elemen vektor jumlah baris $\mathbf{r}$ adalah matriks Dr dengan ukuran ( $\boldsymbol{I} \boldsymbol{x} \boldsymbol{I})$ sedangkan Dc adalah matrik diagonal dengan ukuran $\boldsymbol{J} \boldsymbol{x} \boldsymbol{J}$ dari elemen-elemen vektor jumlah kolom $\mathbf{c}$.

Dari uraian di atas, dapat dinotasikan sebagai berikut:

$-\mathbf{I}_{J}=[n i j] ; n_{i j} \geq 0, \gamma_{i j .}(i=1 \ldots . . I, j=1 \ldots . . J)$

- ${ }_{I} \mathbf{P}_{J}=\frac{1}{n . .} N$ dengan $n . .=\mathbf{I}^{\mathrm{T}} \mathbf{N I}$, dimana $1=[1 \ldots 1]^{\mathrm{T}}$

- Dr $=\operatorname{diag}(\mathbf{r})$ dengan $\mathbf{r}=\mathbf{P I}$ dan

- Dc $=\operatorname{diag}(\mathbf{c})$ dengan $\mathbf{c}=\mathbf{P}^{\mathbf{T}} \mathbf{I}$

Profil baris dan profil kolom dari matrik $\mathbf{P}$ diperoleh dengan cara membagi vektor baris dan vektor kolom dengan masing-masing massanya. Matriks profil baris (R) dan profil kolom $(\mathbf{C})$ dinyatakan oleh:

$\mathbf{R}=\mathbf{D}_{\mathbf{r}}^{-1} \mathbf{P}$ dan $\mathbf{C}=\mathbf{D}_{\mathbf{c}}^{-1} \mathbf{P}^{\mathbf{T}}$

(Greenacre, M.J. 1984)

\subsubsection{Penentuan Jarak Profil}

Untuk menghitung jarak profil baris/ kolom dalam kategori yang sama, digunakan jarak chi-square, yang didefinisikan:

Jarak antara dua individu baris ke- $i$ dan ke- $i$ ' adalah :

$$
d^{2}\left(i, i^{\prime}\right)=\sum_{j=1}^{J} \frac{1}{f ._{j}}\left(\frac{f_{i j}}{f i .}-\frac{f_{i^{\prime} j}}{f_{i^{\prime} .}}\right)^{2}
$$

Jarak antara dua variabel kolom ke- $j$ dan ke- $j$ ' adalah :

$$
d^{2}\left(j, j^{\prime}\right)=\sum_{i=1}^{J} \frac{1}{f_{i .}}\left(\frac{f_{i j}}{f_{. j}}-\frac{f_{i^{\prime} j}}{f_{. j^{\prime}}}\right)^{2}
$$

dimana :

$$
i=(1, \ldots \ldots . I) \text { dan } j=(1, \ldots \ldots . J)
$$

$f i j=$ Frekuensi relatif sel baris ke- $i$ kolom ke- $j$

$f i .=$ Frekuensi relatif baris ke- $i$

$f . j=$ Frekuensi relatif kolom ke- $j$

(Lebart, L, Morineau, Warwick, K.M. 1984)

\subsubsection{Penguraian Nilai Singular (Singular Value Decompotition)}


Untuk mereduksi dimensi data berdasarkan keragaman data ( nilai eigen / inersia) terbesar dengan mempertahankan informasi yang optimum, diperlukan penguraian nilai singular. Penguraian nilai singular (SVD) merupakan salah satu konsep Aljabar matriks dan konsep eigendecomposition yang terdiri dari nilai eigen dan vektor eigen. Di bawah ini adalah ringkasan materi yang dikutip dari buku Greenacre, M.J. 1984. Penguraian nilai singular diekspresikan dalam I x J matriks A dengan rank $\boldsymbol{K}$ dilakukan berdasarkan :

$A_{I \times J}=U_{I \times K} D_{\lambda(K \times K)} V_{K \times J}^{T}$

Atau

$A=\sum_{K=1}^{K} \lambda_{K} U_{K} V_{K}^{T}$

dimana :

$\mathbf{U}=$ vektor eigen matriks $\mathbf{A A}^{T}$

$\mathbf{D}_{\lambda}=$ matriks diagonal $\lambda$ dengan $\lambda^{2}$ nilai eigen tak nol

$\mathbf{V}=$ vektor eigen matriks $\mathbf{A}^{T} \mathbf{A}$

$K=$ Rank matriks A

$U^{T} U=V^{T} V=I \operatorname{dan} \lambda_{1} \geq \lambda_{2} \geq \ldots . . \lambda_{k}>0$

Elemen-elemen $\lambda_{1}, \lambda_{2}, . . \lambda_{k}$ dari matriks diagonal $\mathbf{D}_{\lambda}$ disebut nilai singular dari A. Berdasarkan sifat penguraian nilai singular ini dapat dibentuk matriks :

$$
\mathbf{F}=\mathbf{U D}_{\lambda} \operatorname{dan} \mathbf{G}=\mathbf{V D} \boldsymbol{D}_{\lambda}
$$

dengan unsur - unsurnya menyatakan koordinat baris dan kolom dari matriks $\mathbf{A}$.

\subsubsection{Penguraian Nilai Singular Umum}

Secara umum penguraian nilai singular dari matriks $\mathrm{P}$ adalah :

$P-r c^{T}=A D_{\mu} B^{T}$

dengan syarat :

$\left.A^{T} D_{r}^{-1} A=B^{T} D_{C}^{-1} B=I ; \mu_{1}>\mu_{2}\right\rangle \ldots \mu_{K}>0$

dan didefinisikan :

$\mathbf{A}=$ Matriks yang elemennya adalah vektor eigen matriks $\left(P-r c^{T}\right)\left(P-r c^{T}\right)^{T}$

$\mathbf{B}=$ Matriks yang elemennya adalah vektor eigen matriks $\left(P-r c^{T}\right)^{T}\left(P-r c^{T}\right)$

$\mathbf{D}_{\mu}=$ Matriks diagonal $\mu$ dengan $\mu^{2}$ nilai eigen tak nol.

Tiap himpunan titik dapat dihubungkan dengan sumbu utama dari himpunan titik yang lain yaitu :

$F=D_{r}^{-1} A D_{\mu}$ dan $G=D_{c}^{-1} B D_{\mu}$

\subsubsection{Dekomposisi Inersia}

Nilai inersia menunjukkan kontribusi dari baris ke- $i$ pada inersia total. Sedangkan yang dimaksud inersia total adalah jumlah bobot kuadrat jarak titik - titik ke pusat, massa dan metric(jarak) yang didefinisikan:

Inersia Total baris :

$\operatorname{in}(I)=\sum_{i=1}^{I} r i(r i-c)^{T} D_{c}^{-1}(r i-c)$

Inersia Total kolom ;

$\operatorname{in}(J)=\sum_{i=1}^{j} c j(c i-r)^{T} D_{r}^{-1}(c j-r)$

Jumlah bobot kuadrat koordinat titik dalam sumbu utama ke - $k$ pada tiap tiap himpunan yaitu $\mu_{k}^{2}$ yang dinotasikan dengan $\lambda_{k}$. Nilai ini disebut sebagai 
Inersia Utama ke $-k$. Persamaan Inersia Utama baris dan kolom serta pusatnya dapat dinyatakan sebagai :

$$
\begin{aligned}
& \text { Inersia Utama baris : } \\
& F^{T} D_{r} F=D_{\mu}^{2} \equiv D_{\lambda} \\
& \text { Inersia Utama kolom : } \\
& G^{T} D_{c} G=D_{\mu}^{2}=D_{\lambda} \quad \text { (Greenacre, M.J. 1984) }
\end{aligned}
$$

\section{Metode Penelitian}

Populasi dalam penelitian ini adalah pelaku tindak pidana (penghuni) Rumah Tahanan Negara (RUTAN) Gresik. Sampel penelitian yang diambil dari populasi tersebut berjumlah 273 orang pelaku tindak pidana di Rumah Tahanan Negara (RUTAN) Gresik pada bulan Desember 2008 - Februari 2009.

\subsection{Variabel Penelitian dan Definisi Operasional}

\subsubsection{Variabel Penelitian}

Ada 2 variabel dalam penelitian ini yaitu :

a. Variabel Bebas (Independent Variable)

Sebagai variabel bebas di sini adalah usia, jenis kelamin, tingkat pendidikan, pekerjaan dan alasan melakukan tindak pidana.

b. Variabel Tak Bebas (Dependent Variable)

Sedangkan variabel tak bebas di sini adalah tindak pidana.

\subsubsection{Definisi Operasional}

\section{a. Tindak Pidana}

Perbuatan yang melanggar larangan yang diatur oleh aturan hukum yang diancam dengan sanksi pidana.

Dalam hal ini kategori tindak pidana adalah:

1. Tindak Pidana Pencurian.

2. Tindak Pidana Penipuan.

3. Tindak Pidana Penganiayaan.

4. Tindak Pidana Penadahan.

5. Tindak Pidana Narkoba.

6. Tindak Pidana Perjudian.

7. Tindak Pidana Gangguan Keamanan.

b. Usia Pelaku

Dalam hal ini usia pelaku saat melakukan tindak pidana. Kategori yang diambil adalah :
1. Anak-anak :6-12 thn.
2. Remaja : $13-17$ thn.
3. Dewasa $: 18-45$ thn.
4. Tua $: \geq 46$ thn.

(Http: //tanyasaja.detik.com/pertanyaan/4131-berapa-standart-patokan-usiayang-dipakai. Date : 28-02-2009).

c. Jenis Kelamin

Dalam hal ini kategori yang diambil adalah :

1. Pria

2. Wanita

d. Tingkat Pendidikan

Proses pengubahan sikap dan tata laku seseorang atau kelompok orang dalam usaha mendewasakan manusia melalui upaya pengajaran dan pelatihan.

Dalam hal ini kategori yang diambil adalah :

1. Tidak Lulus SD (TL SD)

2. SD

3. SMP

4. SMA-PT

e. Pekerjaan 
Segala sesuatu yang dilakukan untuk mendapatkan nafkah (sebelum masuk RUTAN). Dalam hal ini kategori yang diambil adalah :

1. Bekerja

2. Tidak Bekerja

f. Alasan melakukan tindak pidana

Alasan dari pelaku tindak pidana melakukan suatu tindak pidana digolongkan menjadi :

1. Ekonomi

2. Pengaruh Lingkungan

3. Alasan Keluarga (Broken Home) dan dendam.

\section{2. $\quad$ Metode Analisis Data}

1. Uji Chi - square untuk mengetahui hubungan antara tindak pidana dengan usia, jenis kelamin, tingkat pendidikan, pekerjaan dan alasan melakukan tindak pidana.

2. Analisis korespondensi untuk mengetahui karakteristik tindak pidana.

\section{Hasil dan Pembahasan}

\subsection{Profil}

Data kriminologi Rumah Tahanan Negara (RUTAN) Gresik dari bulan Desember 2008 - Februari 2009 tercatat masing-masing pelaku tindak pidana pencurian sebanyak 86 orang, 29 orang pelaku tidak pidana penipuan, 16 orang pelaku tidak pidana penganiayaan, 17 orang pelaku tidak pidana penadahan, 33 orang pelaku tidak pidana narkoba, 49 pelaku tidak pidana perjudian dan 43 orang pelaku tidak pidana gangguan keamanan. Grafik 4.1. menunjukkan prosentase pelaku tindak pidana.

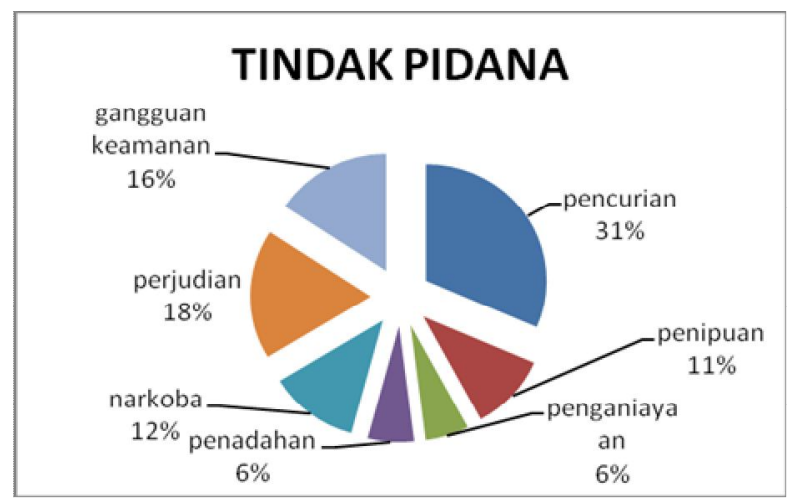

Grafik 4.1. Tindak Pidana

Tabulasi data pada Tabel 4.1. menunjukkan jumlah dan prosentase pelaku tindak pidana berdasarkan usia, jenis kelamin, tingkat pendidikan, pekerjaan dan alasan melakukan tindak pidana.

Berdasarkan hasil perhitungan pada Tabel 4.1. yang berupa pemaparan informasi mengenai tindak pidana di RUTAN Gresik pada periode Desember 2008 - Februari 2009. Tindak pidana menurut umur, ternyata paling banyak pelaku tindak pidana adalah mereka yang berusia dewasa sebesar $63.37 \%$. Untuk tindak pidana berdasarkan jenis kelamin nampak bahwa tindak pidana sebagian besar dilakukan oleh laki-laki sebesar $78.39 \%$ dan $21.61 \%$ dilakukan oleh perempuan. Jika dilihat dari segi pendidikan, tindak pidana $30 \%$ dilakukan oleh terpidana dengan tingkat pendidikan SMA - Perguruan Tinggi. Berdasarkan pekerjaan, diketahui bahwa $69,96 \%$ pelaku tindak pidana adalah mereka yang sudah bekerja dan 30,04\% belum bekerja. Alasan melakukan tindak pidana karena alasan ekonomi sebesar $42,86 \%$ selebihnya alasan lingkungan, kel. \& dendam masing-masing $32,97 \%$ dan $24,18 \%$. 
Tabel 4.1. Jumlah dan Prosentase Pelaku Tindak Pidana

\begin{tabular}{|l|l|c|c|}
\hline \multicolumn{2}{|c|}{ Variabel Pelaku } & Jumlah & Prosentase \\
\hline & & & \\
\hline & anak-remaja & 35 & $12.82 \%$ \\
\hline & dewasa & 173 & $63.37 \%$ \\
\hline & tua & 65 & $23.81 \%$ \\
\hline & & & \\
\hline & laki-laki & 214 & $78.39 \%$ \\
\hline Tingkat pendidikan kelamin & perempuan & 59 & $21.61 \%$ \\
\hline & & & \\
\hline & TL SD & 51 & $18.68 \%$ \\
\hline & SD & 67 & $24.54 \%$ \\
\hline & SMP & 73 & $26.74 \%$ \\
\hline Pekerjaan & $\geq$ SMA & 82 & $30.04 \%$ \\
\hline & & & \\
\hline & bekerja & 191 & $69.96 \%$ \\
\hline Alasan Melakukan & tidak bekerja & 82 & $30.04 \%$ \\
\hline & & & \\
\hline & ekonomi & 117 & $42.86 \%$ \\
\hline & lingkungan & 90 & $32.97 \%$ \\
\hline & kel \& dendam & 66 & $24.18 \%$ \\
\hline
\end{tabular}

Tabel 4.2. Hasil Uji Independensi

\begin{tabular}{|l|c|c|c|}
\cline { 2 - 3 } \multicolumn{1}{c|}{} & Statistik Uji & $\mathrm{db}$ & P Value \\
\hline Usia \& Tindak Pidana & 61,771 & 12 & 0,00 \\
\hline Jenis Kelamin \& Tindak Pidana & 24,205 & 6 & 0,00 \\
\hline Tingkat Pendidikan \& Tindak Pidana & 58,637 & 18 & 0,00 \\
\hline Pekerjaan \& Tindak Pidana & 28,056 & 6 & 0,00 \\
\hline Alasan \& Tindak Pidana & 45,602 & 12 & 0,00 \\
\hline
\end{tabular}

Berdasarkan pada hasil perhitungan analisis Crosstab (tabulasi silang) $P$ Value lebih kecil dari $\alpha$, maka dapat dikatakan terdapat keterkaitan masing-masing tindak pidana dengan usia, jenis kelamin, tingkat pendidikan, pekerjaan dan alasan melakukan tindak pidana, artinya ada tindak pidana tertentu yang banyak terjadi dikarenakan faktor usia, jenis kelamin, tingkat pendidikan, pekerjaan dan alasan melakukan tindak pidana. Untuk mengetahui di mana letak dominasinya diperlukan suatu analisis lanjutan yaitu Analisis Korespondensi. Analisis Korespondensi dilakukan antara tindak pidana dengan usia, pendidikan dan alasan melakukan tindak pidana, karena jenis kelamin dan pekerjaan hanya memiliki dua kategori sehingga cukup dilakukan uji independensi.

\subsection{Analisis Korespondensi Usia dengan Tindak Pidana}

Tabel 4.3. Profil Baris Berdasar Usia

\begin{tabular}{|l|c|c|c|c|c|c|c|}
\hline \multicolumn{1}{|c|}{ Pelaku } & Pencurian & Penipuan & Penganiayaan & Penadahan & Narkoba & Perjudian & Aman \\
\hline Anak-Remaja & 0.143 & 0 & 0.143 & 0 & 0.314 & 0.314 & 0.086 \\
\hline Dewasa & 0.416 & 0.121 & 0.035 & 0.081 & 0.104 & 0.121 & 0.121 \\
\hline Tua & 0.138 & 0.123 & 0.077 & 0.046 & 0.062 & 0.262 & 0.292 \\
\hline Mass & 0.315 & 0.106 & 0.059 & 0.062 & 0.121 & 0.179 & 0.158 \\
\hline
\end{tabular}

Nilai massa terbesar $(0,315)$ terdapat pada tindak pidana pencurian, yang merupakan modus dari data. Jika diperhatikan profil setiap kolom : 
1. Tindak pidana pencurian dan penadahan adalah pada baris pelaku tindak pidana usia dewasa, yang menunjukkan bahwa pelaku tindak pidana usia dewasa cenderung malakukan tindak pidana pencurian dan sedikit penadahan.

2. Tindak pidana penipuan pada baris pelaku tindak pidana usia tua, yang menunjukkan bahwa pelaku tindak pidana usia tua cenderung melakukan tindak pidana penipuan.

3. Tindak pidana penganiayaan, narkoba dan perjudian adalah pada baris pelaku tindak pidana usia anak-remaja, yang menunjukkan bahwa pelaku tinak pidana usia anakremaja cenderung melakukan tindak pidana penganiayaan, narkoba dan perjudian.

Tabel 4.4. Profil Kolom Berdasarkan Usia

\begin{tabular}{|l|c|c|c|c|c|c|c|c|}
\hline \multicolumn{1}{|c|}{ Pelaku } & Pencurian & Penipuan & Penganiayaan & Penadahan & Narkoba & Perjudian & Aman & mass \\
\hline Anak-Remaja & 0.058 & 0 & 0.313 & 0 & 0.333 & 0.224 & 0.07 & 0.128 \\
\hline Dewasa & 0.873 & 0.724 & 0.375 & 0.824 & 0.545 & 0.429 & 0.488 & 0.634 \\
\hline Tua & 0.105 & 0.276 & 0.313 & 0.176 & 0.121 & 0.347 & 0.442 & 0.238 \\
\hline Active Margin & 1.036 & 1 & 1.001 & 1 & 0.999 & 1 & 1 \\
\hline
\end{tabular}

Nilai massa terbesar $(0,634)$ terdapat pada pelaku tindak pidana dewasa, yang merupakan modus dari data. Jika diperhatikan profil setiap baris :

1. Pelaku tindak pidana usia anak-remaja pada kolom narkoba, yang menunjukkan bahwa pelaku tindak pidana usia anak-remaja cenderung malakukan tindak pidana narkoba.

2. Pelaku tindak pidana usia dewasa pada kolom tindak pidana pencurian, yang menunjukkan bahwa pelaku tindak pidana usia dewasa cenderung melakukan tindak pidana pencurian.

3. Pelaku tindak pidana usia tua pada kolom tindak pidana gangguan keamanan, yang menunjukkan bahwa Pelaku tindak pidana usia tua cenderung melakukan tindak pidana gangguan keamanan.

Jika diperhatikan dari kedua profil di atas, baik profil baris atau kolom, terlihat bahwa keduanya menyatakan satu hal yang sama meski dengan tampilan yang berbeda.

Tabel 4.5. Ringkasan Hasil Berdasarkan Usia

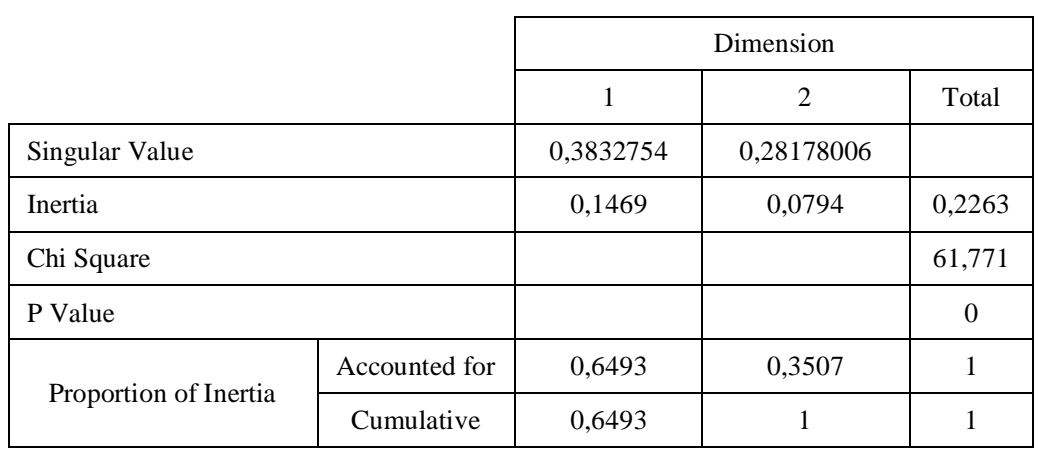

Eigen value (inertia) menunjukkan bahwa nilai varians yang dapat dijelaskan adalah sebesar 0,2263 atau 22,63\% saja. Namun demikian jika dilihat nilai statistik uji Chi square cukup besar dengan nilai p value 0,000 lebih kecil dari alpha yang ditentukan., maka hal ni memperlihatkan bahwa terdapat hubungan yang sangat signifikan antara tindak pidana dengan pelaku tindak pidana berdasarkan usia.

Korelasi kanonik maksimum (yang merupakan interpretasi dari singular value yang merupakan akar kuadrat dari eigen value) antar katagori variabel-variabel dalam analisis untuk setiap dimensi adalah 0,383 untuk dimensi pertama(terbesar), 0,282 untuk dimensi kedua. Dari eigen vektor yang diperoleh dalam analisis (proportion of inertia), maka dengan dua faktor dapat dinyatakan bahwa variabilitas yang dapat dijelaskan adalah sebesar $100 \%$ dengan rincian 
1. Faktor pertama dengan eigen value sebesar 0,1469 mampu menjelaskan variabilitas data sebesar $64,93 \%$.

2. Faktor kedua dengan eigen value sebesar 0,0794 mampu menjelaskan variabilitas data sebesar $35,07 \%$.

Jika kedua figur digabungkan, maka akan didapatkan figure akhir yang memperlihatkan pemetaan karakteristik pelaku tindak pidana dengan tindak pidana. Figur dimaksud ditampilkan sebagai berikut :

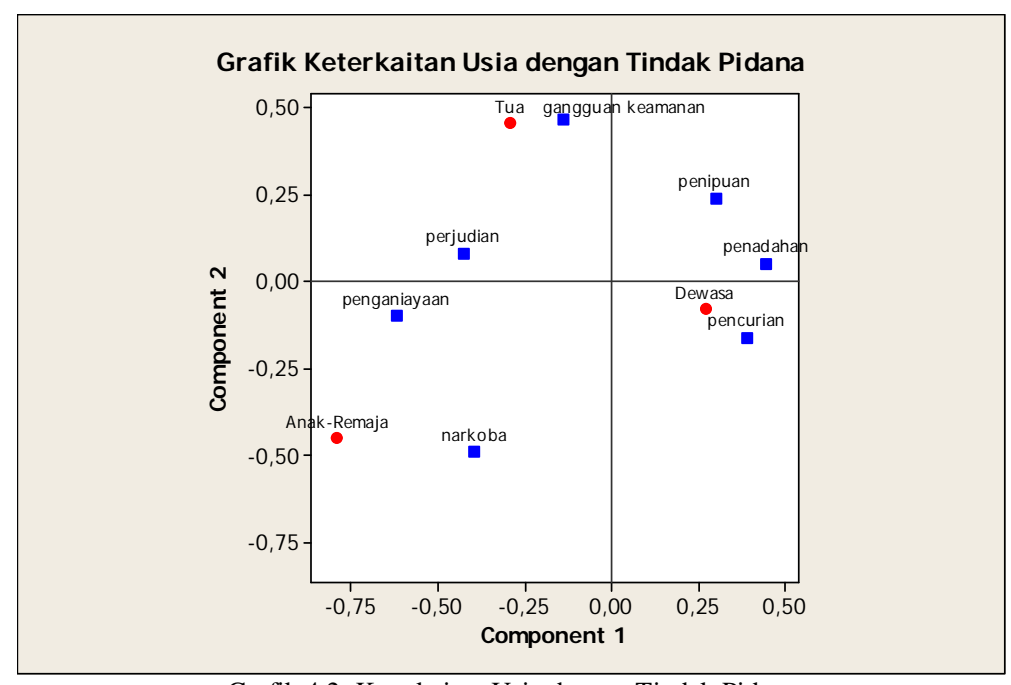

Grafik 4.2. Keterkaitan Usia dengan Tindak Pidana

Dari Grafik 4.2. dapat dilihat bahwa karakteristik tindak pidana narkoba, penganiayaan dan perjudian cenderung dilakukan oleh pelaku tindak pidana usia anak-remaja. Pelaku tindak pidana usia dewasa cenderung melakukan tindak pidana pencurian, penadahan dan penipuan. Tindak pidana gangguan keamanan dan perjudian cenderung dilakukan oleh pelaku tindak pidana usia tua.

\subsection{Analisis Korespondensi Tingkat Pendidikan dengan Tindak Pidana}

Tabel 4.6. Profil Baris Berdasarkan Tingkat Pendidikan

\begin{tabular}{|l|c|c|c|c|c|c|c|}
\hline \multicolumn{1}{|c|}{ Pelaku } & Pencurian & Penipuan & Penganiayaan & Penadahan & Narkoba & Perjudian & Aman \\
\hline TL SD & 0.373 & 0.059 & 0.078 & 0.039 & 0.02 & 0.314 & 0.118 \\
\hline SD & 0.343 & 0.075 & 0.03 & 0.045 & 0.045 & 0.164 & 0.299 \\
\hline SMP & 0.342 & 0.137 & 0.055 & 0.041 & 0.082 & 0.205 & 0.137 \\
\hline SMA - PT & 0.232 & 0.134 & 0.073 & 0.11 & 0.280 & 0.085 & 0.085 \\
\hline Mass & 0.315 & 0.106 & 0.059 & 0.062 & 0.121 & 0.179 & 0.158 \\
\hline
\end{tabular}

Nilai massa terbesar $(0,315)$ terdapat pada tindak pidana pencurian, yang merupakan modus dari data. Jika diperhatikan profil setiap kolom :

1. Tindak pidana pencurian, penganiayaan dan perjudian terletak pada baris pelaku tindak pidana tingkat pendidikan tidak lulus SD, yang menunjukkan bahwa umumnya pelaku tindak pidana tingkat pendidikan tidak lulus SD cenderung malakukan tindak pidana pencurian, perjudian dan sedikit penganiayaan.

2. Tindak pidana gangguan keamanan terletak pada baris pelaku tindak pidana dengan tingkat pendidikan SD, yang menunjukkan bahwa pelaku tindak pidana tingkat pendidikan SD cenderung melakukan tindak pidana gangguan keamanan. 
3. Tindak pidana penipuan terletak pada baris pelaku tindak pidana dengan tingkat pendidikan SMP, yang menunjukkan bahwa pelaku tindak pidana tingkat pendidikan SMP cenderung melakukan tindak pidana penipuan.

4. Tindak pidana narkoba, dan penadahan terletak pada baris pelaku tindak pidana dengan tingkat pendidikan SMA-PT, yang menunjukkan bahwa pelaku tindak pidana dengan tingkat pendidikan SMA-PT cenderung melakukan tindak pidana narkoba, dan sedikit penadahan.

Tabel 4.7. Profil Baris Berdasarkan Tingkat Pendidikan

\begin{tabular}{|l|c|c|c|c|c|c|c|c|}
\hline \multicolumn{1}{|c|}{ Pelaku } & Pencurian & Penipuan & Penganiayaan & Penadahan & Narkoba & Perjudian & Aman & mass \\
\hline TL SD & 0.221 & 0.103 & 0.25 & 0.118 & 0.03 & 0.327 & 0.14 & 0.14 \\
\hline SD & 0.267 & 0.172 & 0.125 & 0.176 & 0.091 & 0.224 & 0.465 & 0.465 \\
\hline SMP & 0.291 & 0.345 & 0.25 & 0.176 & 0.182 & 0.306 & 0.233 & 0.233 \\
\hline SMA - PT & 0.221 & 0.379 & 0.375 & 0.529 & 0.697 & 0.143 & 0.163 & 0.163 \\
\hline
\end{tabular}

Nilai massa terbesar $(0,300)$ terdapat pada pelaku tindak pidana dengan tingkat pendidikan SMA-PT, yang merupakan modus dari data. Jika diperhatikan profil setiap baris :

1. Pelaku tindak pidana dengan tingkat pendidikan tidak lulus SD terletak pada kolom perjudian, yang menunjukkan bahwa pelaku tindak pidana dengan tingkat pendidikan tidak lulus SD cenderung malakukan tindak pidana perjudian.

2. Pelaku tindak pidana dengan tingkat pendidikan SD terletak pada kolom gangguan keamanan, yang menunjukkan bahwa pelaku tindak pidana dengan tingkat pendidikan SD cenderung malakukan tindak pidana gangguan keamanan.

3. Pelaku tindak pidana dengan tingkat pendidikan SMP terletak pada kolom penipuan, yang menunjukkan bahwa pelaku tindak pidana dengan tingkat pendidikan SMP cenderung malakukan tindak pidana penipuan.

4. Pelaku tindak pidana dengan tingkat pendidikan SMA-PT terletak pada kolom narkoba, yang menunjukkan bahwa pelaku tindak pidana dengan tingkat pendidikan SMA-PT cenderung malakukan tindak pidana narkoba.

Jika diperhatikan dari kedua profil di atas, baik profil baris atau kolom, terlihat bahwa keduanya menyatakan satu hal yang sama meski dengan tampilan yang berbeda.

Tabel 4.8. Ringkasan Hasil Berdasarkan Tingkat Pendidikan

\begin{tabular}{|c|c|c|c|c|}
\hline & \multicolumn{3}{|c|}{ Dimension } \\
\hline & & 1 & 2 & Total \\
\hline \multicolumn{2}{|l|}{ Singular Value } & 0.4058325 & 0.20736441 & \\
\hline \multicolumn{2}{|l|}{ Inertia } & 0.1647 & 0.043 & 0.2077 \\
\hline \multicolumn{2}{|l|}{ Chi Square } & & & 58.637 \\
\hline \multicolumn{2}{|l|}{ P Value } & & & 0 \\
\hline \multirow[t]{2}{*}{ Proportion of Inertia } & $\begin{array}{c}\text { Accounted } \\
\text { for }\end{array}$ & 0.767 & 0.2 & 0.967 \\
\hline & Cumulative & 0.767 & 0.967 & 1 \\
\hline
\end{tabular}

Eigen value (inertia) menunjukkan bahwa nilai varians yang dapat dijelaskan adalah sebesar 0,2077 atau 20,77\% saja. Namun demikian jika dilihat nilai statistik uji Chi square cukup besar yaitu 58,637 dengan nilai p value 0,000 lebih kecil dari alpha yang ditentukan., maka hal ni memperlihatkan bahwa terdapat hubungan yang sangat signifikan antara tindak pidana dengan pelaku tindak pidana berdasarkan tingkat pendidikan.

Korelasi kanonik maksimum (yang merupakan interpretasi dari singular value yang merupakan akar kuadrat dari eigen value) antar katagori variabel-variabel dalam analisis untuk setiap dimensi adalah 0,406 untuk dimensi pertama(terbesar), 0,207 untuk dimensi kedua. Dari eigen vektor yang diperoleh dalam analisis (proportion of inertia), maka dengan dua faktor 
dapat dinyatakan bahwa variabilitas yang dapat dijelaskan adalah sebesar 96,7\% dengan rincian :

1. Faktor pertama dengan eigen value sebesar 0,1647 mampu menjelaskan variabilitas data sebesar $76,7 \%$.

2. Faktor kedua dengan eigen value sebesar 0,043 mampu menjelaskan variabilitas data sebesar $20 \%$.

Jika kedua figur digabungkan, maka akan didapatkan figure akhir yang memperlihatkan pemetaan karakteristik pelaku tindak pidana dengan tindak pidana. Figur dimaksud ditampilkan sebagai berikut :

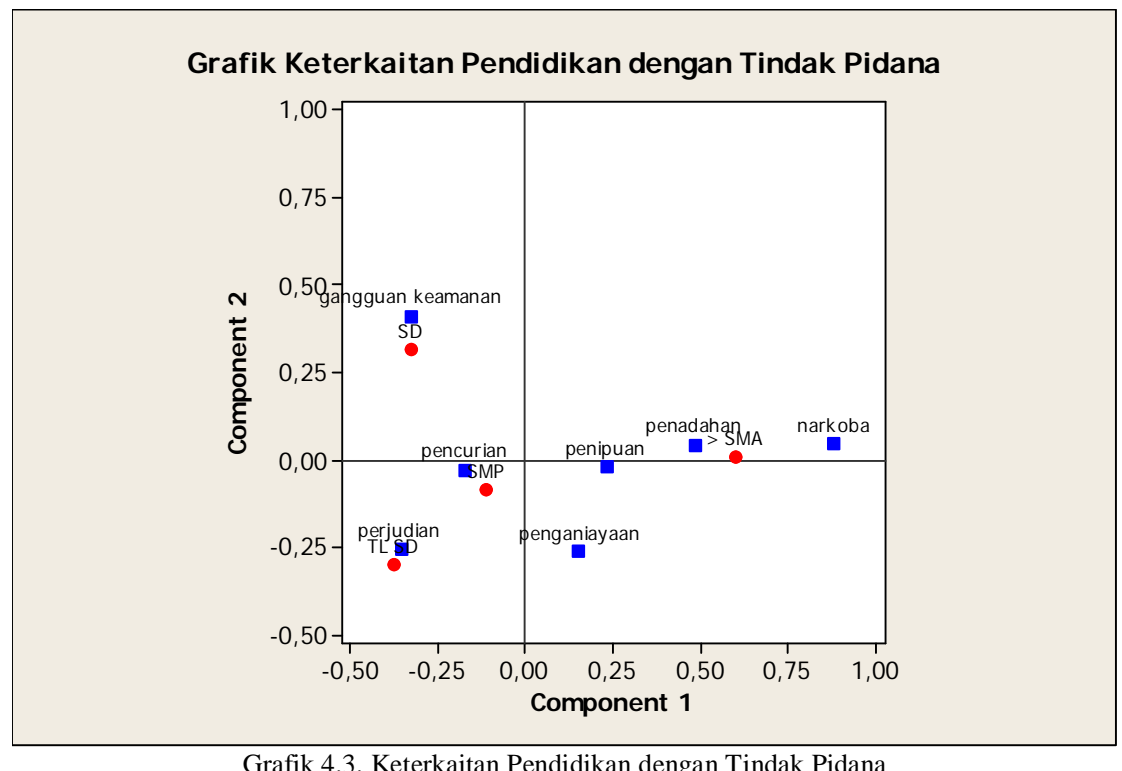

Berdasarkan Grafik 4.3. dapat dilihat bahwa karakteristik tindak pidana perjudian, pencurian dan penganiayaan cenderung dilakukan oleh pelaku tindak pidana mereka yang tidak lulus SD. Untuk tindak pidana gangguan keamanan cenderung dilakukan oleh pelaku tindak pidana dengan tingkat pendidikan SD. Tindak pidana pencurian dan penipuan cenderung dilakukan oleh pelaku tindak pidana dengan tingkat pendidikan SMP. Untuk tindak pidana narkoba sedikit penadahan cenderung dilakukan oleh pelaku tindak pidana dengan tingkat pendidikan SMA-PT.

Tabel 4.9. Profil Baris Berdasarkan Alasan Melakukan Tidak Pidana

\begin{tabular}{|l|c|c|c|c|c|c|c|}
\hline \multicolumn{1}{|c|}{ Pelaku } & Pencurian & Penipuan & Penganiayaan & Penadahan & Narkoba & Perjudian & Aman \\
\hline Ekonomi & 0.453 & 0.145 & 0.017 & 0.077 & 0,060 & 0.154 & 0.094 \\
\hline Lingkungan & 0.267 & 0.089 & 0.044 & 0.056 & 0.144 & 0.211 & 0.189 \\
\hline $\begin{array}{l}\text { Keluarga \& } \\
\text { Dendam }\end{array}$ & 0.136 & 0.061 & 0.152 & 0.045 & 0.197 & 0.182 & 0.227 \\
\hline Mass & 0.315 & 0.106 & 0.059 & 0.062 & 0.121 & 0.179 & 0.158 \\
\hline
\end{tabular}

Nilai massa terbesar $(0,315)$ terdapat pada tindak pidana pencurian, yang merupakan modus dari data. Jika diperhatikan profil setiap kolom :

1. Tindak pidana pencurian, penipuan dan penadahan terletak pada baris pelaku tindak pidana dengan alasan ekonomi, yang menunjukkan bahwa umumnya pelaku tindak pidana dengan alasan ekonomi cenderung malakukan tindak pidana pencurian, penipuan dan penadahan.

2. Tindak pidana perjudian terletak pada baris pelaku tindak pidana dengan alas an lingkungan, yang menunjukkan bahwa pelaku tindak pidana dengan alas an lingkungan cenderung melakukan tindak pidana perjudian. 
3. Tindak pidanapenganiayaan, narkoba dan gangguan keamanan penipuan terletak pada baris pelaku tindak pidana dengan alas an keluarga dan dendam, yang menunjukkan bahwa pelaku tindak pidana dengan alas an dendam cenderung melakukan tindak pidana penganiayaan, narkoba dan gangguan keamanan.

Tabel 4.10. Profil Baris Berdasarkan Alasan Melakukan Tidak Pidana

\begin{tabular}{|l|c|c|c|c|c|c|c|c|}
\hline \multicolumn{1}{|c|}{ Pelaku } & Pencurian & Penipuan & Penganiayaan & Penadahan & Narkoba & Perjudian & Aman & mass \\
\hline Ekonomi & 0.616 & 0.586 & 0.125 & 0.529 & 0.212 & 0.367 & 0.256 & 0,429 \\
\hline Lingkungan & 0.279 & 0.276 & 0.25 & 0.294 & 0.394 & 0.388 & 0.395 & 0.33 \\
\hline $\begin{array}{l}\text { Keluarga \& } \\
\text { Dendam }\end{array}$ & 0.105 & 0.138 & 0.625 & 0.176 & 0.394 & 0.245 & 0.349 & 0.242 \\
\hline
\end{tabular}

Nilai massa terbesar $(0,429)$ terdapat pada pelaku tindak pidana dengan alas an ekonomi, yang merupakan modus dari data. Jika diperhatikan profil setiap baris :

1. Pelaku tindak pidana dengan alas an ekonomi terletak pada kolom tindak pidana pencurian, yang menunjukkan bahwa pelaku tindak pidana dengan alas an ekonomi cenderung malakukan tindak pidana pencurian.

2. Pelaku tindak pidana dengan alas an lingkungan terletak pada kolom gangguan keamanan, yang menunjukkan bahwa pelaku tindak pidana dengan alasan lingkungan cenderung malakukan tindak pidana gangguan keamanan.

3. Pelaku tindak pidana dengan alas an keluarga dan dendam terletak pada kolom tindak pidana penganiayaan, yang menunjukkan bahwa pelaku tindak pidana dengan alas an keluarga dan dendam cenderung malakukan tindak pidana penganiayaan.

Jika diperhatikan dari kedua profil di atas, baik profil baris atau kolom, terlihat bahwa keduanya menyatakan satu hal yang sama meski dengan tampilan yang berbeda.

Tabel 4.11. Ringkasan Hasil Berdasarkan Alasan Melakukan Tindak Pidana

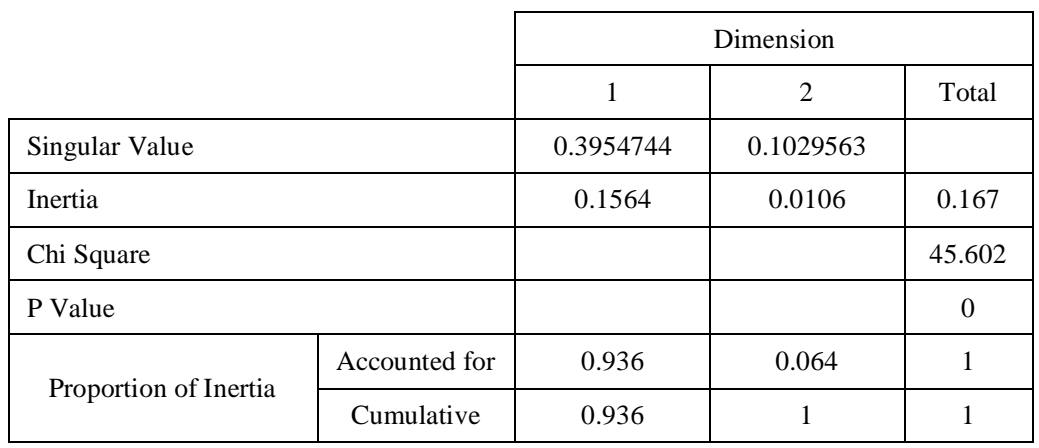

Eigen value (inertia) menunjukkan bahwa nilai varians yang dapat dijelaskan adalah sebesar 0,167 atau $16.7 \%$ saja. Namun demikian jika dilihat nilai statistik uji Chi square cukup besar yaitu 45.602 dengan nilai p value 0,000 lebih kecil dari alpha yang ditentukan., maka hal ni memperlihatkan bahwa terdapat hubungan yang sangat signifikan antara tindak pidana dengan pelaku tindak pidana berdasarkan alas an melakukan tindak pidana.

Korelasi kanonik maksimum (yang merupakan interpretasi dari singular value yang merupakan akar kuadrat dari eigen value) antar katagori variabel-variabel dalam analisis untuk setiap dimensi adalah 0,395 untuk dimensi pertama(terbesar), 0,103 untuk dimensi kedua. Dari eigen vektor yang diperoleh dalam analisis (proportion of inertia), maka dengan dua faktor dapat dinyatakan bahwa variabilitas yang dapat dijelaskan adalah sebesar $100 \%$ dengan rincian :

1. Faktor pertama dengan eigen value sebesar 0,1564 mampu menjelaskan variabilitas data sebesar $93.6 \%$.

2. Faktor kedua dengan eigen value sebesar 0,011 mampu menjelaskan variabilitas data sebesar $6.4 \%$. 
Jika kedua figur digabungkan, maka akan didapatkan figure akhir yang memperlihatkan pemetaan karakteristik pelaku tindak pidana dengan tindak pidana. Figur dimaksud ditampilkan sebagai berikut :

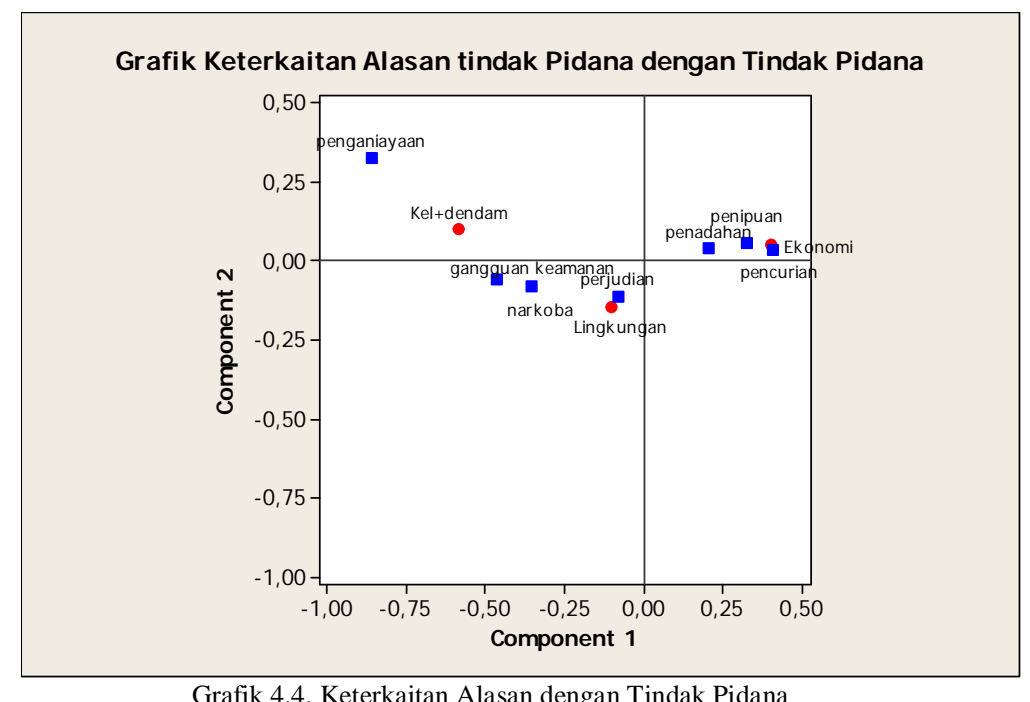

Berdasarkan Grafik 4.4. dapat dilihat bahwa karakteristik tindak pidana pencurian, penipuan dan penadahan cenderung dilakukan oleh pelaku tindak pidana dengan alasan ekonomi. Untuk tindak pidana perjudian cenderung dilakukan oleh pelaku tindak pidana dengan alasan lingkungan. Tindak pidana penganiayaan, narkoba dan gangguan keamanan cenderung dilakukan oleh pelaku tindak pidana dengan alasan keluarga dan dendam.

\section{Simpulan dan Saran.}

\subsection{Simpulan.}

Berdasarkan hasil analisa data dengan pengelompokan terhadap tindak pidana, usia, jenis kelamin, tingkat pendidikan, pekerjaan dan alasan melakukan tindak pidana dapat ditarik kesimpulan sebagai berikut :

1. Ada keterkaitan masing-masing tindak pidana dengan usia, jenis kelamin, pendidikan, pekerjaan dan alasan melakukan tindak pidana. Artinya ada tindak pidana tertentu banyak dilakukan pada seseorang dengan faktor usia, jenis kelamin, pendidikan, pekerjaan dan alasan tertentu.

2. Proporsi tindak pidana secara keseluruhan terhadap jenis kelamin adalah sebagai berikut :

a. Tindak pidana yang dilakukan oleh pria sebesar $78.39 \%$

b. Tindak pidana yang dilakukan oleh wanita sebesar $21.61 \%$

3. Hasil pemetaan memperlihatkan bahwa :

a. Berdasarkan Usia :

Tindak pidana narkoba, penganiayaan dan perjudian cenderung dilakukan oleh pelaku tindak pidana usia anak-remaja. Pelaku tindak pidana usia dewasa cenderung melakukan tindak pidana pencurian, penadahan dan penipuan. Tindak pidana gangguan keamanan dan perjudian cenderung dilakukan oleh pelaku tindak pidana usia tua.

b. Berdasarkan Tingkat Pendidikan :

Tindak pidana perjudian, pencurian dan penganiayaan cenderung dilakukan oleh pelaku tindak pidana mereka yang tidak lulus SD. Untuk tindak pidana gangguan keamanan cenderung dilakukan oleh pelaku tindak pidana dengan tingkat pendidikan SD. Tindak pidana pencurian dan penipuan cenderung dilakukan oleh pelaku tindak pidana dengan tingkat pendidikan SMP. Untuk tindak pidana narkoba dan sedikit penadahan cenderung dilakukan oleh pelaku tindak pidana dengan tingkat pendidikan SMA-PT.

c. Berdasarkan Alasan Melakukan Tindak Pidana : 
Tindak pidana pencurian, penipuan dan penadahan cenderung dilakukan oleh pelaku tindak pidana dengan alasan ekonomi. Untuk tindak pidana perjudian cenderung dilakukan oleh pelaku tindak pidana dengan alasan lingkungan. Tindak pidana penganiayaan, narkoba dan gangguan keamanan cenderung dilakukan oleh pelaku tindak pidana dengan alasan keluarga dan dendam.

\subsection{Saran}

Sehubungan dengan masalah dan hasil penelitian, maka peneliti mencoba memberikan beberapa saran dengan harapan dapat bermanfaat sebagai bahan pertimbangan dalam pengambilan kebijaksanaan agar tujuan dari RUTAN dapat tercapai. Dengan mempelajari masalah-masalah, khususnya mengenai banyaknya tindak pidana yang terjadi akhir-akhir ini di daerah Gresik, hendaknya semua pihak yang terkait sadar hukum dan memperhatikan dampak dari setiap kejahatan yang dilakukan.

\section{Daftar Pustaka}

Agresti, Alan (1990), Categorical Data Analysis, John Wiley \& Sons, Inc.,Canada

Benzecri, J., P., (1992), Correspondence Analysis Handbook, Marcel Dekker, Inc., New York

Direktorat Jenderal Pemasyarakatan, Departemen Kehakiman dan HAM. 2001. Pemasyarakatan Dalam Prospektif Membangun Manusia Mandiri. Jakarta : Departemen Kehakiman dan HAM.

Hasan, Iqbal. 2002. Metodologi Penelitian dan Aplikasinya. Jakarta : Ghalia Indonesia.

Http: //tanyasaja.detik.com/pertanyaan/4131-berapa-standart-patokan-usia-yang-dipakai. Date : 28-02-2009.

Johnson R., A., \& Wichern, D., W., (2002) Applied Multivariate Statistical Analysis, Fifth edition, Prentice Hall, New Jersey

Lebart, L,Morineau, A, Warwicck, K.M. (1984), Multivariate Descriptive Statistically Analysis, John Wiley \& Sons, New York.

Moeljatno. 2003. Kitab Undang - Undang Hukum Pidana. Jakarta : PT. Bumi Aksara.

N.,N., (2001), SPSS 10; Correspondence Analysis Output, Faculty of Social and Behavioral Sciences, Leiden University, Leiden-Netherland

RM, Suharto. 2002. Hukum Pidana Materiil. Jakarta : Sinar Grafika.

Sudjana. 1995. Metoda Statistika. Bandung : Tarsito.

Widjanarko Otok, Bambang. “ Analisis Data Kualitatif “. Makalah disajikan pada Seminar Lembaga Penelitian dan Pengabdian Kepada Masyarakat Universitas Airlangga, Surabaya. 